\title{
Stereotyped Roles for Men and Women in Kurdistan Region of Iraq
}

\author{
Nishtiman Othman Mohammed \\ $\mathrm{PhD}$ student in public law \\ Faculty of Law, Political Science and Management-Soran University \\ Email: nishtiman.mohammed@soran.edu.iq \\ Prof Dr. Kameran Hussein Al-Salihi \\ Lecturer at Soran University - Kurdistan of Iraq \\ Email: kameran.salihi@soran.edu.iq \\ Received: February 10, 2020 Accepted: March 12, 2020 Published: April 2, 2020 \\ doi:10.5296/ijssr.v8i2.16788 URL: http://dx.doi.org/10.5296/ijssr.v8i2.16788
}

\begin{abstract}
Discrimination against female draws to a great degree upon the tradition and tribal mentality. The role given to women is to be subordinated to men and be in the service of men and the family. Boys and men are allowed to dominate women in aspects of social life. This stereotypical role assigned to women, based on traditions and tribal mentality, involves not only accepting violence to be administered against women but prescribes even violence.

CEDAW's goal is to achieve equality between men and women to eradicate violence clashes with the local stereotype. CEDAW's tools to bring about the needed changes have been to demand state party to it to translate their textual commitment to legal codes and practices. This paper examines the national legislation of Iraq and Kurdistan to point out the degree of subordination of local laws to CEDAWs Article 5. The findings of this paper are that Kurdistan has introduced important changes to the laws but in regard to child marriage it has not reached the international standards.
\end{abstract}

Keywords: marriage, penal code, domestic violence, honor killing, gender, Sharia Law 


\section{Introduction}

Gender stereotypes are people's views about men's and women's characteristics. Stereotypical material differs among societies (Martin, 2001). The conviction that boys and girls need to be treated differently, that girls need to be well-behaved, for example, while boys are permitted more liberty just because they are boys is one foundational stereotype.

Article 5(a) of the CEDAW requires State parties to CEDAW to eliminate all damaging methods and dangerous practices that draw on the concept of inferiority of women, and the stereotypical positions assigned to men and women.

The 'sub-section (b) of this article examines some of the most common traditionalist cultural norms that disadvantages women and their roles in childcare assigned to women' (Holtmaat, 2011, p142)

Negative and harmful traditional, cultural, religious, or customary convictions, thought, laws, and procedures involving women role at home or in public should be substituted by favorable recognition of the contribution of women to community and by acceptance of taking decisive part in caring and upbringing of children.

As such, sub-sections of Article 5 have dual roles, eliminating the negative practices and stereotypes and inculcating instead a positive attitude toward women contributions. Article 5(b) focuses on educational requirements, it demands that State Parties 'ensure that family education includes a proper understanding of maternity as a social function and the recognition of the common responsibility of men and women in the upbringing and development of their children (Holtmaat, 2011, p142).

Article 5 recognizes that the foundation of discrimination against women lies in gender stereotypes and institutionalized personal gender roles. It reflects the awareness that without eradicating these factors, eliminating all types of discrimination against women is difficult (Committee on the Elimination of Discrimination against Women, 2008, para 16). The Committee of CEDAW remains worried about the persistence of patriarchal attitudes and deep-rooted stereotypes about men and women's position and duties in community that discriminate against women (2008, para 17). The Committee is also concerned that the preservation of traditional social practices and attitudes unfavourable to women perpetuate the subordination of women in community and is a severe barrier to enjoyment by women of their fundamental rights.

In addition, the Committee invites the State Party to adopt steps in accordance with Articles 2(f) and 5(a) of the Convention to eliminate social procedures and stereotypes that discriminate against women. It encourages the State Party to collaborate with civil society organisations, groups of women and community officials, educators and the media in this respect (Committee on the Elimination of Discrimination against Women, 2008).

The Committee urges the State Party to step up its attempts to develop and execute educational and awareness-raising programs aimed at women and men at all stages of society with a aim of establishing and encouraging an atmosphere that eliminates stereotypes that 
discriminate against women and enable women to practice their basic rights. It also calls on the State Party to check the steps adopted to evaluate their effect on a regular basis, to adopt suitable intervention and submit to the Committee in its next report.

\section{Legal Measures to Prevent Stereotyped Roles}

Social and cultural traditions must be adapted so that sex or gender is not the factor upon which the statuses of men and women are decided. Moreover, educational inputs are needed to ensure that families are taught that men and women share accountability when it comes to their children' upbringing.

The family is considered to be Iraq's key fundamental unit of society. It is specifically provided for in Article 29(1) of the Constitution. It also invites the State to maintain the religious, moral and national values of the family institution. The family is the basis of society; its religious, moral and national norms are preserved by the State. Paragraph 4 of the said Article prevents all types of abuse and violence, where all types of abuse and violence shall be prohibited in the family, society and school.

Historically, in many Iraqi societies, domestic violence including physical, sexual and psychological abuse has occurred, but it is very hard to understand its magnitude because such abuse is generally handled as a family affair and is rarely reported to the police. The Iraqi Constitution also prohibits unlawful entry into one's house, the exception to which is a court order. This clause is aimed at defending the right to privacy, but it also makes it more difficult for police to take action in domestic violence cases (Article 17 of the Constitution).

Social stereotypes codifying violence against women play an important role in the on-going violence against women, and the concepts and practices that underpin violence and discrimination against women in Iraq and Kurdistan are well recognized; they limit and restrict the position of women in society through social stereotypes and customs and unfairly depict the essence of women. Despite significant advancement towards modernisation, Kurdish society is still traditional and patriarchal to a large extent, which regards the domination of women by men as the norm. These norms which restrict the freedoms of women are based on complicated practices, costumes, religion and tribal attitudes. They, to a significant degree, govern assumptions about what moral and immoral behaviour, marriage, divorce, property, inheritance, and custody rights of women (European Parliament, 2007, P.50).

A family's attempts to implement these culturally-assigned gender roles may result in domestic violence, including crimes of honor and forced marriage, while the closed nature of society may make it hard for women to flee violent circumstances. All types of domestic violence take place all over Iraqi Kurdistan; however, addressing such violence is either usually overlooked and women are expected to give in, or if addressed it would be usually discriminatory against women and kept within the family.

Here it needs to be said that we cannot fully understand why violence is greater disproportionally in Islamic countries without noting the role of Islam itself. Islam clearly prescribes beating of wife; 
As to those women on whose part you see ill-conduct, admonish them (first), (next), refuse to share their beds, (and last) beat them, but if they return to obedience, seek not against them means (of annoyance). Surely, Allah is Ever Most High, Most Great. (The Quran, Al nisa: 34)

It noteworthy, to point out that several regulations have been enacted by the Kurdish parliament to ensure greater protection of women's human rights, including outlawing domestic violence and polygamy - this is not to say that there is blanket ban on polygamy because even in Kurdistan the system allows husband to have a second wife when the first is infertile.

\section{Female Genital Mutilation}

One of the most inhumane acts of gender-based violence in the world is female genital mutilation (FGM) (UNFPA, 2019). The motives and factors behind FGM are deeply rooted within tradition and cultural heritage and are complicated and hard to identify (Ismail, 2009,p19). As described and defined by the World Health Organization, 'FGM includes all processes involving partial or complete removal of external female genitalia or other damage to female genital bodies for non-medical purposes,' and from the point of view of human rights, FGM is regarded to be an excessive type of discrimination against women as well as a breach of protection of the children's rights when conducted on minors, as usually is case. Additionally, the practice of FGM violates the female's rights to health, safety and physical dignity, the right to be safe and free from torture and unfair or degrading treatment, and the right to life when the practice leads to death. As such, a wide variety of international organizations are dedicated to eliminating FGM (UNICEF, Heartland Alliance International and High Council of Women Affairs, 2016, p.3). Less than 10\% of the entire female population in Iraq has suffered from FGM. However, the frequency or rate of practicing FGM is disconcertingly higher in the region of Kurdistan (Yasin et al., 2013, p2). "FGM is a violation against the humanity of a woman," said Pakhshan Zangana, Secretary General of the High Council of Women's Affairs in Kurdistan, "The exercise of FGM deprives women of their will, dehumanizes them, and must be totally eliminated from Kurdistan"(The Guardian, 2014).

General Recommendation No 14 of the CEDAW Committee proposes that State Parties take suitable and effective steps to eradicate the exercise of FGM, and No 24 of the general recommendation stipulates that these signatory countries should guarantee that regulations prohibiting FGM are enacted and enforced effectively. Article 29(3) of the Iraqi Constitution prohibits 'all types of violence and abuse within the family and holds the family's commitment to guarantee this in the highest esteem. There is no legislation in Iraq specifically banning FGM. In Kurdistan Region, however, a law of Combating Domestic Violence is enacted which criminalizes the exercise of FGM and penalizes individuals who "instigate, help or perform" the process. Penalties for FGM offenders range from 6 months to 3 years imprisonment. However, its application still faces obstacles, as it has failed to accomplish its planned objective of establishing women's legal security owing to the lack of guidelines on the implementation of the law and the inability to finalize the development of the law-stipulated reconciliation committees. 
FGM is in violation of Article 5 of the CEDAW and Article 29(3) of the Constitution of Iraq, as well as the obligation to be safe from all types of discrimination against women and the right to life and physical dignity, including liberty from violence. FGM contradicts Article 1 of the Women's Convention on gender-based "discrimination against women" since it victimises women and prevents them from enjoying of their fundamental rights as equal to men and causes them to suffer physical and emotional pain (Kerubo, 2010,P.15).

Despite the enactment of the law, however, the government has not yet adopted any measures for its activation. That is why the frequency of incidences of this phenomenon is still high. Strict laws need to be enforced to prevent people from subjecting their daughters to the practice. The significance of prosecuting female genital mutilation practitioners and parents who expose their daughters to female genital mutilation should be prescribed and demanded by such laws. However, effective enforcement of these laws remains a real challenge. Human Rights Watch mentioned that a woman from Rania said that because there is a law now, so people don't talk about it as much as before, but if people in my village or another village want their girls to undergo it, they can still do it secretly (Human Rights Watch, 2012). According to the report, FGM is still prevalent. It also notes that the subjection of daughters to FGM is correlated with the mother's level of education. On average, as a mother's level of education increases the likelihood of her daughter undergoing FGM decreases (HCWA, HAI, UNICEF, 2015-2016, p 15). FGM was more prevalent in rural areas than in urban areas and this accords with the fact that most rural women are not as educated as urban women. When mothers were asked about their plans to cut or not to cut their daughters, only $4.3 \%$ stated that they intend to have FGM performed for their daughter. According to a report Summary FGM Prevalence Study Survey in the Kurdistan Region of Iraq, 63.4\% of mothers surveyed said that they are carrying out FGM on their daughters in compliance with religious requirement. Just over $24.0 \%$ said that FGM was done as a result of family pressure. Among mothers whose daughters had not undergone FGM/C, about $40.0 \%$ said that they did not force their daughters to be cut because FGM/C was not part of their tradition and $23.5 \%$ said that their religion forbade it (HCWA, HAI, UNICEF, 2015-2016, p 17). Moreover, report summary FGM prevalence study survey in the Kurdistan Region showed that just over 50\% of respondents were aware that there was a law prohibiting FGM. The rate was much lower in Dohuk (19.7\%) compared to each of the other three governorates $(66.0 \%)$. The majority of mothers $(67.5 \%)$ believed that greater awareness of and enforcement of the law would help reduce the practice of $\mathrm{FGM} / \mathrm{C}$. Mothers felt that the best way to strengthen the law was through information campaigns from the government using media $(61.0 \%)$, better enforcement of the law (58.7\%), increased vocal support from religious leaders $(56.5 \%)$, education in schools (50.4), and information campaigns by civil society organizations $(47.3 \%)$.

\section{Pretexts to Mitigating Punishment for Women Abusers}

Under Article 41 of the Iraqi Penal Code, there is no offense if the deed is committed while practicing a legal right. The penalizing of a wife by her husband, the disciplining of children by parents and teachers under their authority within certain limits is prescribed by law or by custom (the Penal Law No. 111 of 1969, Article 41 (1)). 
Article 41 can therefore be seen to confirm the legal right of a husband to punish his spouse. The problem here is that the Article 41 does elaborate what such punishment involves. This can therefore be taken advantage of to inflict physical and mental abuse of the woman. It is noteworthy that the Articles 41 does not draw the proper boundaries to keep this "punishment" in check. This shortcoming of legal codes coincides unfortunately with the lack of customary restrictions to provide sufficient protection for women. This entails that women do not have protections neither legal nor customary.

Many Iraqi conservative or Islamic leaning legal specialists have voiced their concerns that an amendment to this clause may be incompatible with the prevalent culture and custom of Iraq and as well as certain interpretations of Islamic law. This discrimination, however, appears to violate Articles 14 of the Constitution, as well as 5 and 15 of the CEDAW. It violates Article 29(4) of the Constitution, which says that "all forms of violence and abuse in the family, school, and society shall be prohibited".

The objection from Islamic point of view is not convincing completely. In Turkey, which is an Islamic and developing country, deny this "right" to husbands. On the contrary, the Turkish Penal Code demands a prison term of up to 30 months if a member of a family is dealt with in ways other than care and compassion. In Jordan, another Islamic and developing country, the CEDAW Committee suggests that the population there have developed awareness that victimizing wife is not compatible with Islamic teaching. The cases of these two Islamic and developing countries undermine the religious-leaning Iraqi legal experts, mentioned above, since there can always be more than one interpretation of Islamic teachings (UN Committee on the Elimination of Discrimination Against Women , 2006,p 9).

This abovementioned section of Article 41 was amended by the Kurdistani Parliament's Law No 7 of 2001. According to this amendment, the punishment of a woman by her husband is considered a crime. However, the law suffers a major shortcoming. It does not prescribe a punishment for the violence. Without such a prescription it will be left for the judges' discretion, and considering that they are mostly conservative, male, and more often than not, religious means that they will choose the lightest punishment.

This brings attention to another Kurdistan law. Article 2 (1) of No 8 (2011) of Combating Domestic Violence, which states that family members perpetrating domestic violence, such as sexual, physical and psychological abuse within the family against his or her other family member are punishable either by imprisonment or fine. The law says: "whoever commits a domestic violence is imprisoned for no less than six months and no more than three years and fined for no less than one million Iraqi dinars and no more than five million Iraqi dinars or punished by one of these two penalties".

As such, we could say that this amendment complied with CEDAW and the Iraqi constitution, and it is another step toward gender equality.

Here, Kurdish authorities and civil society organisations, addressing gender equality, can benefit from considering the Rwandan experiment. Rwanda, it is known, have seen one of the worst atrocities in after WWII era, and disproportionate part of that atrocities was inflicted on 
women. As a measure to avert similar tragedies, it seems that government undertook investment in educating the population about gender-based discrimination particularly against women in a patriarchal society. Consequently, a substantial improvement in the perceptions of people about the position of women and girls in society has occurred. Rwandan civil society's intensive initiatives and activism are creating strides in altering patriarchal thinking. One of the most effective approaches for maintaining the sustainability of gender-equality gains in Rwanda was to reach men. Because of this program, Rwandan men participate rigoursly in promoting gender equality and preventing violence against women and girls. Rwanda also set a harsher deterrence against spousal abuse. An individual who is convicted of assaulting physically or sexually his or her partner will face a term of imprisonment for a period of no less than three (3) years and no more than five (5) years (Article 137 Law $\mathrm{N}^{\mathrm{o}} 68 / 2018$ of 30/08/2018 determining offences and penalties in general, Rwanda).

\section{Crimes of Honor}

The concept of honor crimes involves all types of individual violence in the name of honor (Idriss, 2011, p.1). It is described as violence perpetrated by a family member, usually a man, against another family member who is deemed to have brought shame on the family or tribe (Faqir, 2001, p.65; Danish Immigration Service, 2018). The aim of such an act is to safeguard the family or extended family's dignity or honor. Men are committing the vast bulk of honor-related offenses against women, although men are also sometimes victimized by such offenses. The violence of honor killings is anchored in the notion that a family's honor relies on its female members, whose activities and sexuality need to be controlled to prevent bringing shame on the whole family. Violence in the name of honor is found in regions where tribal traditions or conservative customs steeped in religion hold power. A tribe or a family will violently attack any member, typically a woman, who has acted in a way that causes the family or tribe to feel ashamed. It can involve physical violence, house arrest, limitation of movement, prevention of education, compulsory marriage, assassination or forced suicide (United Kingdom: Home office, 2017 ; Puttick, 2015, p26). Honor killings in Iraqi Kurdistan are thought to be the second most prevalent source of death among women after death from natural causes. The Pass Blue web page quotes the UN as saying that about 50 honor killings are practiced every month in Iraqi Kurdistan, but most of them go unreported (Higgs \& Rudzite, 2014). In some cases, a death by suicide is in fact an honor killing by the family (United States Department of State, 2017). In Iraqi Kurdistan, approximately 300 to 400 women are burned alive each year. These fatalities are often recorded as suicides, but are also often associated with domestic violence or honoring violence (Lattimer, 2017, p. 21).

An honor killing is usually practiced in the following situations: adultery, premarital sex, reluctance to marry a person selected by the father or brother, wanting to marry a man who is deemed unacceptable by the family, becoming a victim of rape, or simply being suspected of "sexual misconducts". Women who are suspected of having sullied the honor face death generally. But there can also be other types of violence such as disfigurement, persisting torture that force the women to commit suicide, and house detention. Under Article 19 of the Iraqi Constitution, committing a crime of honor is forbidden; "there is no crime or punishment except by legislation". Yet, this Article has almost being revoked by the Iraqi 
Penal Code (Article 409), which prescribes a reduced an imprisonment sentence of no more than three years for a man who kills his mahram, a wife a female under his charge, or/and woman's lover if he catches them in bed. This Code even demands that no legal defence should be brought against a man using such a justification, nor can the Aggravating Circumstance Laws apply against him (Iraqi panel code No 111 of 1969).

This provision of the Iraqi Penal Code represents discrimination against women because it is a legal justification for a decreased penalty for males who kill in defense of their honor. This does not extend to a female who uncovers and murders her husband or his partner involved in adultery in the marital bed.

A range of human rights organizations, including UNAMI, are concerned about the high rate of honour killings (UNAMI Human Rights Report, 2009, p 3), and has suggested that this defense be abolished. The CEDAW Committee encouraged Iraq to condemn and eliminate honor killings and to ensure that these crimes are charged and be punishable in the same manner as other killings (United Nations report, 2000, para194). In addition, the Committee suggested that the measures and policies to combat family violence should include laws to bar reference to honor in relation to murdering a woman (CEDAW General Recommendation No. 19, 1992, para25 (r) (ii)).

Prevention of honor killing falls under Article 29(4) of the Iraqi Constitution, which says that 'all types of violence and family abuse shall be forbidden.' Honour killing violates the right to ' 'life, safety and freedom' provided for in Article 15 of the Constitution of Iraq. The Constitution prohibits penalty or vengeance outside of or without trial; stipulating that 'deprivation or limitation of the right to life, safety and freedom' is forbidden only in compliance with the law and on the basis of a judgment by qualified judiciary (Article 15 (2) Iraqi Constitution 2005) and that 'the accused is innocent until found guilty in a fair trial' (Article 19 (5) Iraqi Constitution 2005).

When we compare Iraq with other developing countries, Iraq will be judged as lagging behind. In Tunisia, for instance, the excuse of killing on the bases of honor is rejected as mitigating factor (Zuhur, 2005, p. 26). In Lebanon, the penalty is equivalent for both women and men (UN Committee on the Elimination of Discrimination Against Women, 2006, p. 12), as it is in Jordan.

In Kurdistan, this Article has been amended by Parliament as follows: "Committing crimes against women to protect honor is not considered as mitigating factor to reduce legal punishment (Law No. 14 of 2002 Kurdistan). However, this amendment does not demand a harsh term for the murder which means that judge, particularly the conservative one, can impose the lightest possible penalty commensurable with the crime.

Article 128(1) of Iraqi Penal Code states that legal excuse either discharges a person from a penalty or reduces that penalty. Excuse only exists under conditions that are specified by law. Notwithstanding these conditions, perpetrating of an offence with honorable motives or in response to the unjustified and serious provocation of a victim of an offence is considered a mitigating excuse. Unfortunately, the exclusion of honor as a motivation is not stated in Iraqi 
legal codes. This allows a wide discretion to judges to reduce penalty in punishing honor killing, by deferring to Article 130, which allows drastic reduction of sentences. According to 130 , a death penalty can be reduced to no less than one year of imprisonment, and a penalty of life imprisonment to no less than 6 months when there are mitigating factors.

The issue here is cultural to a great degree. Religious authorities and judges, who usually come from their folds, consider sexual infidelity of a woman as a "dishonouring act" against her husband and family. This is the reason why judges in Iraq are so inclined to defer to Article 130 in their handling of the cases of murdering women.

As such we can suspect Articles 128 and 130 violate Article 14 of the Constitution, which is meant to guaranteeing equality and non- discrimination based on sex. These articles also contradict Article 2(b) and (c), 4, 5 and 15 of CEDAW. The CEDAW, in its general recommendation no. 19, states that legislation must remove the defence of honour in criminal cases (CEDAW Committee, 1992, para 25 (r) (ii)). These two articles of penal code also violates Article 29 (4) of the Constitution, which states that 'all forms of violence and abuse in the family... shall be prohibited.' The constitution forbids punishment or revenge outside the law or without trial; stating that deprivation or restriction of the rights to life, security and liberty 'is prohibited except in accordance with the law and based on a decision issued by a competent judicial authority (Article 15 of Iraqi Constitution 2005), that 'there is no crime or punishment except by law (Article 19 (2) of Iraqi Constitution 2005) and that 'the Accused is innocent until proven guilty in a fair trial'(Article 19 (5) of Iraqi Constitution 2005). Fortunately, in Kurdistan, Articles 128, 130, and 131 have been revoked by Law 14 of 2002 in regard to presenting mitigates factors to male perpetrator.

Despite the fact that the laws condemns honour killing as crimes, the data from the Directorate for Combating Violence against Women in Kurdistan show an alarming incidences of killing women. In 2015 there were reported 55 cases of murders against women. In 2016 there the number went down to 43 (Landinfo, 2018, p.10). However, in 2018 the number climbed to 46 . This does not mean we can draw much conclusion from the rise and fall of the numbers of the cases. The reason might be that many more cases are not reported and no one is persecuted for those hidden crimes (General Directorate of Combating Violence Against Women, 2018, p.7). There might also be many more cases of honour killing however they are presented as self-immolation. The suspicion is that husbands, in-laws, parents or brother and other male relatives set the women on fire and report it as self-immolation. However, suspecting reported self-immolation as cases of honour killing does not deny that real self-immolation do not happen. But even in these cases we should consider the responsibility of the women's social network for their fate. Certain women are subjected to constant physical, sexual and mental torture and the feel trapped without any hope of change. Consequently, they resort to setting themselves alight as a way to escape and also to signal that their lives have been no less than the hell which they are usually threatened by through religiously informed "advice".

\section{Child/Early Marriages}

Child marriage is described as a marriage involving a child under the age of 18, and it 
impacts women disproportionately. UNICEF's stand is that child marriage is a type of child abuse (UNICEF, 2017). Because of a multitude of variables, child marriage remains a fact of life for many girls around the world. These variables include poverty, absence of opportunities for education and work, insecurity in the midst of war and struggle, and the strength of tradition and custom (Malhotra, 2010, P.3). In addition, some parents believe that their daughters are protected and their financial security increased by marriage. Child marriage, however, exposes girls to many safety issues and violence (International Women's Health Coalition). Child marriage has adverse psychological impact on the child. Legally in many countries, the mere wedding night would be counted as statutory rape. Girls are still deemed to be children before they attain the age of 18 (Naqrachi, 2014, P.220).

Iraqi child marriage laws fall short of the global standard. This is evidenced in the Article 41 of Iraqi Constitution (2005) which clearly states that Iraqis are free in their commitment to their personal status according to their religions, sects, beliefs, or choices, and this shall be regulated by law. This Article of the constitution paves the way for the legislatures to enact laws to legalize child marriage. Such an attempt has already been made and resulted in presenting a draft of the so-called the Ja'afari Personal Status Law to the Iraqi Parliament in 2014 which would have allowed children as young as 9 years of age to be married (UNFPA, 2016, p.5). Fortunately, the Iraqi Parliament refused to accept the changes to the Iraqi Personal Status Law (Human Rights Watch, 2017).

This refusal meant the current law (Article (8) of Iraqi Personal Status Code) will be kept in force. However, this law allows child marriage if a judge authorizes it for girls above 15 years old who is deemed capable physically to entering marriage. Still, it is more equitable than the draft suggested, the Ja'afari Personal Status Law, since it would have allowed the marriage of children from the age of 9 years old without any need for judicial authorization.

The Iraqi Article (8), though, has been amended in KRG by the Law No. 15 of 2008. However, the amendment is quite superficial. It requires that the judge can authorize the marriage of 16 years old person. So the whole amendment is about adding just one year. This means that the lawful age of marriage as spelled out in this Article is still below the internationally recognised standard. The Iraqi, including that of Kurdistan, legislatures should adopt the international standards. Ironically, Article 2 of the KRI Domestic Violence Law No. 8 (2011) describes child marriage as an act of domestic violence. Article 7 of the Domestic Violence Law enforces a penalty of 6 months to 3 years imprisonment with a fine of 1 to 5 million Iraqi dinars on any individual that is thought to have undertaken an act of domestic violence such as child marriage.

Yet, this contradicts the politics of Kurdistan legislature. The very Kurdistan parliament has allowed the marriage of 16 years old persons - under certain conditions including that it is authorized by a court - who are legally children. So one suspects the motivation behind the Law No. 8 (2011). More to the point, this law regards the marriage of underage as an act of domestic violence, yet it contradicts the Law No. 15 of 2008 which allows child marriage under 18 - even though it is stipulated that it should be authorized by a court. So why should KRI make a law criminalizing child marriage but does not abolish another law which allows 
child marriage. Our speculation about the motive is that it is just a matter of showing off to Western public opinion that Kurdistan is progressive and has criminalized child marriage. Iraq and Kurdistan could have followed the lead of Rwanda's law which stipulates legal the age of marriage to be 21 years old (Article 168 No. 32 of 2016 Law Governing Person and Family).

So what have been the practical implications of the lack of serious commitment, on the one hand, and the lack of the willingness to harmonize the laws in a way to promote the cause of women equality.

In 2011, data from Iraq's Central Statistics Bureau showed that 5\% of Iraqi girls were married before the age of 15 , while $22 \%$ of Iraqi girls married before the age of 18 . For Iraqi Kurdistan, these proportions are about the same (UNFPA, 2016, p.2). Child marriage contracts are usually signed informally outside the courts and without formal registration in the Kurdistan Region and Iraq, thereby allowing for unreliable data and underreporting on the real rates of child marriage (UNFPA, 2016, p.3). According to the report by the E-kurd Daily (2011) child marriage were most frequently reported in the areas of Ranya, Chwarqurna, Hajiawa, Betwate and Pishder (Muradkan-Shaker, 2011). However, there appear to be no mechanisms for monitoring early and forced marriages, even the contracts are signed through court procedures, and therefore to ensure that those responsible for marriages that violate the law are prosecuted (Home Office UK Border Agency, 2009, p.91).

\section{Conclusions}

When compared with Iraq, we noticed a significant improvement in Kurdistan Region of Iraq.

One of the major contributors for this improvement was the enacting of the Law No. 8 (2011), which has served the interests of women in various aspects of social interaction. A clause of this Law prohibited female genital mutilation, and that was unprecedented in Iraqi Kurdistan, indeed, the whole practice was denied and the practice was exercised without much restriction.

It also issued a prohibition against wife beating by amending the Penal Code Law, Article 41 . Moreover, in Article 2 of Law No. 8 of 2011, it has forbidden any acts of physical, sexual, psychological violence within the family.

Kurdistan legislatures have also amended Article 409 of Iraqi Penal Code. This means rejecting any mitigating factors as a reason to commute sentences against violence against women who are accused of being caught in the act of sexual infidelity by husband.

Regarding child marriage, Kurdistan has risen the age of marriage to 16 years provided that a judge accepts the marriage arrangement. In the meantime, Article 2 of the Law of Domestic Violence No. 8 (2011) has deemed child marriage as an act of domestic violence. Obviously, this Law contradicts the minimum marriage age set by Kurdistan parliament in personal status code, which is 16 , even though it requires authorization by a judge. 


\section{Suggestions}

1. The Law 409 should be amended so that it specifies the punishment sentence against women murderers and does not leave sentencing to the discretion of judge, who are usually male and conservative.

2. The minimum age of marriage should be risen to 18 years old on par with the international standards.

\section{References}

Danish Immigration Service. (2018). Kurdistan Region of Iraq (KRI): Women and men in honour-related conflicts. Retrieved November 9, 2018, from https://www.refworld.org/docid/5beacadd4.html

European Parliament. (2007). Directorate General for Internal Policies, Policy Department C: Citizens Rights and Constitutional Affairs. Brussels.

Faqir, F. (2001). Intrafamily Femicide in Defence of Houour: The Case of Jordan. Third World Quarterly, 22(1), 65-82. https://doi.org/10.1080/713701138

General Directorate of Combating Violence. (2018). Annual Report 2018 Activity and Statistics of General Directorate of Combating Violence against Women. Kurdistan Region of Iraq

HCWA, HAI, UNICEF. (2015-2016). Report Summary FGM Prevalence Study Survey in the Kurdistan Region of Iraq.

Higgs, J., \& Rudzite, L. (2014). In Kurdistan and Beyond, Honor Killings Remind Women They Are Worthless. Pass Blue Independent Coverage of the UN. Retrieved May 6, 2014, from

https://www.passblue.com/2014/05/06/in-kurdistan-and-beyond-honor-killings-remind-wome n-they-are-worthless

Holtmaat, R. (2011). Article 5. In M.A. Freeman, C. Chinkin \& B. Rudolf (Eds), The UN Convention on the Elimination of All Forms of Discrimination against Women: A Commentary. Oxford, Oxford University Press.

Home Office UK Border Agency. (2009). Country of Origin Information Report Kurdistan Regional Government Area of Iraq.

Human Rights Watch. (2012). Iraqi Kurdistan: Law Banning FGM not Being Enforced. Retrieved from https://www.hrw.org/news/2012/08/29/iraqi-kurdistan-law-banning-fgm-not-being-enforced

Human Rights Watch. (2017). Iraq: Parliament Rejects Marriage for 8-Year-Old Girls. from https://www.hrw.org/news/2017/12/17/iraq-parliament-rejects-marriage-8-year-old-girls

Idriss, M. M. (2011). Violence, Women and Islam: an Introduction. In M. M. Idriss \& T. Abbas (Eds), Honour, Violence, Women and Islam. Routledge. 
https://doi.org/10.4324/9780203846988

International Women's Health Coalition. The Facts on Child Marriage: What is Child Marriage? Retrieved from https://iwhc.org/resources/facts-child-marriage/

Ismail, E, A. (2009). Female Genital Mutilation Survey in Somaliland. The Edna Adan Maternity and Teaching Hospital, Hargeisa, Somaliland 2002 to 2009, https://www.bava.org.uk/wp-content/uploads/Edna-Adan-reserach-Somaliland-2009.pdf

Kerubo, K. R. (2010). Female Genital Mutilation and its effects on women and young girls. Diaconia, University of Applied Sciences.

Landinfo. (2018). Kurdistan Region of Iraq (KRI)Women and men in honour-related conflicts. The Danish Immigration Service.

Lattimer, M. (2017). Iraq Practical Cooperation Meeting. EASO COI Meeting Report, Brussels. Retrieved from https://www.ecoi.net/en/file/local/1404903/90_1501570991_easo-2017-07-iraq-meeting-repo rt.pdf

Malhotra, A. (2010) The Causes, Consequences and Solutions to Forced Child Marriage in the Developing World. Testimony Submitted to U.S. House of Representatives Human Rights Commission, International Center for Research on Women Washington, D.C. Retrieved from https://www.icrw.org/files/images/Causes-Consequences-and\%20Solutions-to-Forced-ChildMarriage-Anju-Malhotra-7-15-2010.pdf

Martin, C. L., \& Dinella, L. (2001). Gender-related Development. International Encyclopedia of the Social \& Behavioral Sciences, 6020-6027. https://doi.org/10.1016/B0-08-043076-7/01684-3

Muradkan-Shaker, F. (2011). Iraqi Kurdistan seen from a women's perspective. Retrieved from https://ekurd.net/mismas/articles/misc2011/1/state4550.htm

Naqrachi, A. (2014) Early Marriage in Morocco. In S. Toperich, \& A. (Eds), A New Paradigm: Perspectives on the Changing Mediterranean. Center for Transatlantic Relations.

Puttick, M. (2015). The Lost Women of Iraq: Family-based Violence during Armed Conflict. Ceasefire Centre for Civilian Rights and Minority Rights Group International. Retrieved from https://minorityrights.org/publications/the-lost-women-of-iraq-family-based-violence-duringarmed-conflict/

The Guardian. (2014). Majority in Iraqi Kurdistan Oppose Female Genital Mutilation. Retrieved from https://www.theguardian.com/global-development/2014/sep/08/iraqi-kurdistan-female-genital -mutilation-fgm

UN Committee on the Elimination of Discrimination against Women (CEDAW). (1992). CEDAW General Recommendation No. 19: Violence against women, 1992. Retrieved from https://www.refworld.org/docid/52d920c54.html 


\section{Macrothink}

International Journal of Social Science Research

ISSN 2327-5510

2020, Vol. 8, No. 2

UN Committee on the Elimination of Discrimination against Women (CEDAW). (2006). Consideration of Reports Submitted by States Parties under Article 18 of CEDAW, Combined Third and Fourth Report of States Parties: Jordan. CEDAW/C/JOR/3-4. Retrieved from https://www.refworld.org/publisher,CEDAW,STATEPARTIESREP,JOR,4537783d0,0.html

UN Committee on the Elimination of Discrimination against Women. (2008a). United Nations Convention on the Elimination of All Forms of Discrimination against Women: Concluding observations of the Committee on the Elimination of Discrimination against Women. Forty-second session. 20 October-7 November 2008. Madagascar. CEDAW, $/ \mathrm{C} / \mathrm{MDG} / \mathrm{CO} / 5$.

UN Committee on the Elimination of Discrimination against Women. (2008b). United Nations Convention on the Elimination of All Forms of Discrimination against Women: Concluding comments of the Committee on the Elimination of Discrimination against Women. Burundi. 14 January-1 February 2008. CEDAW/C/BDI/CO/4.

UNAMI. Human Rights Report, January-June. (2009). Retrieved from https://www.ohchr.org/Documents/Countries/IQ/UNAMI_Human_Rights_Report15_January _June_2009_EN.pdf

UNFPA. (2016). Child Marriage in Kurdistan Region- Iraq. Retrieved from https://iraq.unfpa.org/sites/default/files/pub-pdf/Child\%20Marriage\%20Broucher\%20English \%20Final\%20covers\%206.pdf

UNFPA Iraq. (2019). Protecting Girls in Iraq from Female Genital Mutilation. form https://iraq.unfpa.org/en/news/protecting-girls-iraq-female-genital-mutilation,

UNICE. (2017). Child Marriage. UNICEF Rosa/Bronstein. Retrieved from https://www.unicef.org/rosa/what-we-do/child-protection/child-marriage

UNICEF, Heartland Alliance International and High Council of Women Affairs. (2016). Report Summary FGM Prevalence Study Survey in the Kurdistan Region of Iraq 2015-2016. High Council of Women Affairs- Iraq Kurdistan

United Kingdome: Home Office. (2017). Country Policy and Information Note - Iraq: Kurdish 'honour' crimes. Retrieved from https://www.gov.uk/government/publications/iraq-country-policy-and-information-notes

United Nations, Report of the Committee on the Elimination of Discrimination against Women. 22nd and 23nd session. 12-30 June 2000. General Assembly Official Records, Fifty-Fifth Session, Supplement No. 38 (A/55/38).

United States Department of State. (2016). Country Report on Human Rights Practices-Iraq. Retrieved from https://www.refworld.org/country,USDOS,,IRQ,,58ec8a234,0.html

Yasin, B., Al-Tawil, N., \& Al-Hadithi, T. (2013) Female Genital Mutilation Among Iraqi Kurdish Women: A Cross- sectional Study from Erbil City. BMC Public Health, 13(1), 1-8. https://doi.org/10.1186/1471-2458-13-809 


\section{Macrothink \\ International Journal of Social Science Research \\ ISSN 2327-5510 2020, Vol. 8, No. 2}

Zuhur, S. (2005). Gender, Sexuality and the Criminal Laws in the Middle East and North Africa: A comparative Study. Women for Women's Human Rights. WWHR - New Ways

\section{Legilation}

Law No. 14 of 2002 Kurdistan

Article 15 (2) Iraqi Constitution 2005

Article 19(5) Iraqi Constitution 2005

the Penal Law No. 111 of 1969, Article 41 (1)

Article 137 Law No68/2018 of 30/08/2018 determining offences and penalties in general, Rwanda

Article 168 No. 32 of 2016 Law Governing Person and Family, Rwanda

\section{Glossary}

CEDAW : The Convention on the Elimination of all Forms of Discrimination against Women

FGM : $\quad$ Female Genital Mutilation

ID : $\quad$ Iraqi Dinar

KRI : $\quad$ Kurdistan Region of Iraq

UNFPA : $\quad$ United Nations Fund for Population Activities

UNICEF: $\quad$ United Nations Children's Fund

UNAMI : $\quad$ United Nations Assistance Mission for Iraq

\section{Copyrights}

Copyright for this article is retained by the author(s), with first publication rights granted to the journal.

This is an open-access article distributed under the terms and conditions of the Creative Commons Attribution license (http://creativecommons.org/licenses/by/4.0/). 